\title{
Reaction Heat Control for Steam Reforming of Ethanol with Ni-supported Latent Heat Storage Grain
}

\author{
Hiroki SAKal ${ }^{1)}$, Yuta Hasegawa $^{1)}$, Ade Kurniawan $^{2)}$, Takahiro Nomura ${ }^{2 *}$ and Tomohiro AkiYama ${ }^{2)}$ \\ 1) Graduate School of Engineering, Hokkaido University \\ 2) Faculty of Engineering, Hokkaido University
}

Abstract: Waste heat recovery is important in steel making industry. Intermittency of waste heat from batch processes is a barrier to applying heat recovery systems to steel plant. Latent heat storage using Phase Change Material (PCM) is attractive technique to solve this problem. Moreover, effective thermal energy recovery can be achieved by the combination of waste heat utilization and endothermic reaction. In this paper, Ni/Latent-heat-storage grain was fabricated and catalytic performance about ethanol steam reforming was analyzed. The fabricated grains exhibited latent heat of $69.9 \mathrm{~kJ} \mathrm{~kg}^{-1}$ and the latent heat of product didn't change after catalytic performance test. In the performance test, all of the ethanol was cracked and the maximum concentration of $\mathrm{H}_{2}$ in outlet gas flow was $62 \%$. The result of the catalytic test indicated side reaction occurred in the experiment. Heat supply from PCM mitigated temperature change and the mitigation helped to stop decreasing $\mathrm{H}_{2}$ yield in the catalytic reaction.

Keywords: waste heat; latent heat; phase change material; steam reforming; hydrogen.

\section{Waste heat $X$ Latent heat storage $X$ Endothermic reaction}

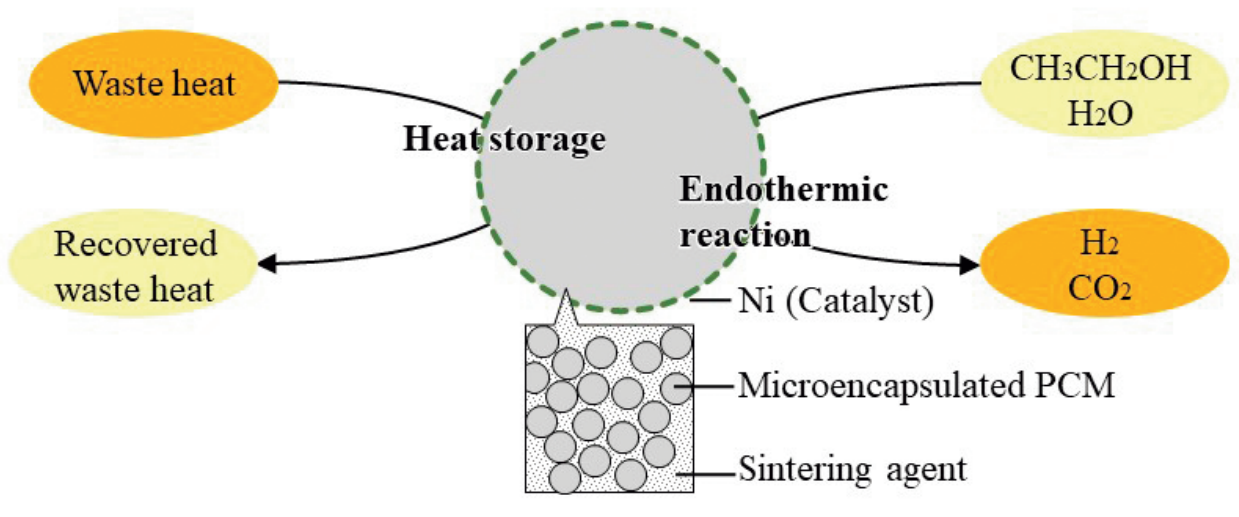

\section{$<$ Ni-supported MEPCM grain $>$}




\title{
$\mathrm{Ni}$ 触媒担持潜熱蓄熱粒子によるエタノール水蒸気改質の 反応熱制御
}

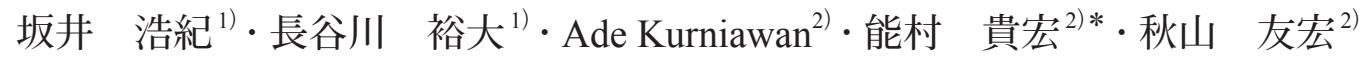

Reaction Heat Control for Steam Reforming of Ethanol with Ni-supported Latent Heat Storage Grain

Hiroki Sakai, Yuta Hasegawa, Ade Kurniawan, Takahiro Nomura and Tomohiro Akiyama

\section{1. 背景}

鉄鋼業には多量のエネルギーが投入されており，2017年 の日本全体の $\mathrm{CO}_{2}$ 排出量の約 $15 \%$ が鉄鋼業由来である。さ らに日本の一次エネルギー供給量の約 $5 \%$ 相当が排熱とし て放出されている。日本の主幹産業である鉄鋼業の $\mathrm{CO}_{2}$ 排 出削減，省エネルギー化の意義は極めて大きい。そのため, 様々な鉄鋼排熱有効利用技術が開発，研究されてきた ${ }^{1-8)}$ 。

高温の排ガス, 排熱が有するエネルギーを回収し再利用 することができれば, 鉄鋼業での大幅な省エネルギー化が 可能である。エクセルギーの観点から高温の熱ほど取り出 せる仕事量は大きい。そのため, 高温排熱は高温熱源とし て利用することが望ましく，効率的な省エネルギー化のた めには利用時の極端な温度低下は避けるべきである5)。ま た，熱を必要とするプロセスで熱源は安定している必要が あり，高温排熱は安定した熱源として供給される必要があ る。一方，鉄鋼業における多くのプロセスがバッチ型のプ ロセスであり，排熱の発生は断続的であり温度変化が大き い。これが, 発生温度が $400^{\circ} \mathrm{C}$ 以上を見込める各種炉排力゙ スが高いエクセルギーを有しているにも関わらず大きなエ クセルギー損失を伴う低圧水蒸気へと変換され, 高温での 熱回収, 再利用が達成されない一因だと考えられる。

断続的に排出される高温排熱を安定した熱源として利用 するためには，蓄熱技術の導入が不可欠である。そこで， 近年，相変化物質（Phase Change Material，PCM）を用いた 潜熱蓄熱技術が注目されている。潜熱蓄熱とは物質の相変 化潜熱を利用した蓄熱法であり，従来高温域で用いられて きた顕熱蓄熱よりも蓄熱密度が高い点が特徵である。ま た, 潜熱蓄熱は蓄・放熱時に蓄熱体である PCMの相変化 温度で一定になるため恒温熱源としても扱える。さらに潜 熱蓄熱は熱の入出力のみで蓄熱可能であるため, 基本的に は複雑かつ精密なプロセスを導入する必要がない。これら
の特徵から, 電炉等のガス排出部分に高融点 PCMを組み 込み, 排ガス温度の変動を抑え, 排熱の利用率を向上させ る機構が提案されている例もある ${ }^{9-11)}$ 。高温域での潜熱蓄 熱技術は鉄鋼業での排熱有効利用のコアテクノロジーとな る可能性がある。

高温鉄鋼排熱を低エクセルギー損失で回収し，回収した エネルギーを中・長期的に貯蔵する方法として排熱回収と 吸熱の化学反応の組み合わせがある。化学反応による排熱 回収は，低質の熱エネルギーを高いエクセルギー率を持つ 化学エネルギーへエクセルギー再生できる。また，メタン， メタノール, エタノール等の化学物質に変換することで, 長期のエネルギー貯蔵が可能となり，利用が容易になる。 さらに，吸熱反応を要する化学製品の製造には熱源として 化石燃料の燃焼が用いられており，この熱源を鉄鋼からの 排熱で置き換えることで $\mathrm{CO}_{2}$ 排出量の削減が見込める。

化学反応の制御には厳密な温度管理が求められるが, 鉄 鋼排熱は間欠的で時間変動が大きいものが多く, 吸熱的化 学反応とインテグレーションすることは困難である。一 方, 潜熱蓄熱デバイスを排熱部に組み込むことで, 熱源 が安定化し，吸熱反応の利用が容易になる。Maruoka らは $\mathrm{PCM}$ として Cuを用い, 吸熱反応にはメタンの水蒸気改質 反応を用いた研究を提案した ${ }^{12-14)}$ 。

我々の研究グループでは金属系 $\mathrm{PCM} /$ セラミックによる コア/シェル型のマイクロカプセル PCM (Microencapsulated PCM, MEPCM) の開発に成功した ${ }^{15-19)}$ 。このMEPCMはコ アに $\mathrm{Al}$ 基合金系の $\mathrm{PCM}$ を シェルに $\mathrm{Al}_{2} \mathrm{O}_{3}$ セラミックを有 するマイクロカプセルである。コアの PCMが融解 ·凝固 することで潜熱蓄熱機能を発揮するが，セラミックシェル で覆われているためセラミック紛体として利用できるのが この材料の特徴である。

そこで本研究ではMEPCMを用いて潜熱蓄熱粒子を作 製し，さらに触媒を担持することで触媒/潜熱蓄熱粒子の

2) 北海道大学工学研究院 (Faculty of Engineering, Hokkaido University)

* Corresponding author. E-mail : nms-tropy@eng.hokudai.ac.jp, Address : Hokkaido University, Kita 13 Nishi 8 Kita-ku Sapporo Hokkaido 060-8628 
調製を試みた。さらに調製した触媒/潜熱蓄熱粒子のエタ ノールの水蒸気改質反応に打ける触媒性能を調査した。工 タノールの水蒸気改質反応の反応式を式 (1) に示す。

$$
\mathrm{C}_{2} \mathrm{H}_{5} \mathrm{OH}+3 \mathrm{H}_{2} \mathrm{O} \rightarrow 6 \mathrm{H}_{2}+2 \mathrm{CO}_{2} \quad \Delta H_{298}=174 \mathrm{~kJ} / \mathrm{mol} \ldots . . \text { (1) }
$$

化石燃料由来である炭化水素の代替原料として, 再生 可能であるバイオマスエタノールが注目されており ${ }^{20)}, \times$ タノールよりも毒性が低く, 安全性が高いという特性を 持つ。加えて, 生成される水素ガスは炭素に代わるエネル ギー源として注目を集めており, 製鉄業でも重要な化学物 質の一つである。本研究では, 水蒸気改質の触媒として $\mathrm{Ni}$ を選択した。調製した Ni触媒/潜熱蓄熱粒子は潜熱蓄熱と 触媒性能を一つの試料で同時に達成できる可能性がある。 本研究では用意した潜熱蓄熱粒子がエタノールの水蒸気改 質反応の熱源として動作しうるかを確認するため, 触媒反 応槽の加熱部分への給電を停止した際の触媒性能を評価し た。

\section{2. 実験方法}

\section{$2 \cdot 1$ 原料}

MEPCM原料としてヒカリ素材工業株式会社製 Al-

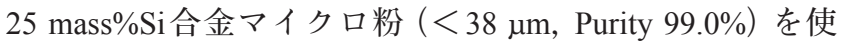
用した。MEPCM作製時の添加剂として高純度化学社製 $\mathrm{Al}$
$(\mathrm{OH})_{3}$ (Purity 99.99\%) を使用した。

潜熱蓄熱粒子製造時の焼結助剤として $\mathrm{AGC}$ 株式会社 (旧旭硝子) 製のガラスフリット $(11 \mu \mathrm{m})$ を用いた。この ガラスフリットの主成分は $\mathrm{SiO}_{2}, \mathrm{~B}_{2} \mathrm{O}_{3}, \mathrm{ZnO}, \mathrm{BaO}, \mathrm{Al}_{2} \mathrm{O}_{3}$, $\mathrm{La}_{2} \mathrm{O}_{3}$ である。

潜熱蓄熱粒子に担持する触媒の $\mathrm{Ni}$ 源には高純度化学社 製硝酸ニッケル六水和物 (Purity 99.9\%) を使用した。水蒸 気改質反応には関東化学社製エタノール（Purity 99.5\%）を 使用した。

\section{$2 \cdot 2$ 触媒担持潜熱蓄熱粒子の調製}

Fig.1 は原料とする Al-25 mass\% $\%$ Si 合金から Ni 担持潜熱蓄 熱粒子 (Ni/MEPCM 粒子) の作製手順を示す。先行研究 ${ }^{17)}$ に基づいて作製した MEPCMを転動造粒法にて粒子状（粒 子サイズ $: 2 \mathrm{~mm}$ ) に成型し, 含浸法によって $\mathrm{Ni}$ を担持した。

蒸留水 $300 \mathrm{ml}$ に $\mathrm{Al}(\mathrm{OH})_{3}$ を $1 \mathrm{~g}$ 投入し, $100^{\circ} \mathrm{C}$ で $2 \mathrm{~h}$ 保持 し, $\mathrm{Al}(\mathrm{OH})_{3}$ の一部を蒸留水に溶解させた。次にアンモニ ア水 $\left(1 \mathrm{~mol} \mathrm{~L}^{-1}\right)$ を用いて水溶液の $\mathrm{pH} 8$ に調整した後, $10 \mathrm{~g}$ の Al-25 mass\%Si合金を投入し，その表面を化成被膜 処理した。化成被膜処理後, 液温を $75^{\circ} \mathrm{C}$ まで冷却し, $16 \mathrm{~h}$ 保持することで水溶液中に溶解した $\mathrm{Al}$ 含有イオンを晶析 させた。晶析操作後, Al- 25 mass $\% \mathrm{Si}$ 合金由来の粉体を，混 合している $\mathrm{Al}(\mathrm{OH})_{3}$ と水溶液からろ過, 分離し，一昼夜乾 燥させた。

次に，潜熱蓄熱粒子を転動造粒法にて成型した。ガラス フリットとMEPCMを1：1の重量比で遊星ボールミルに

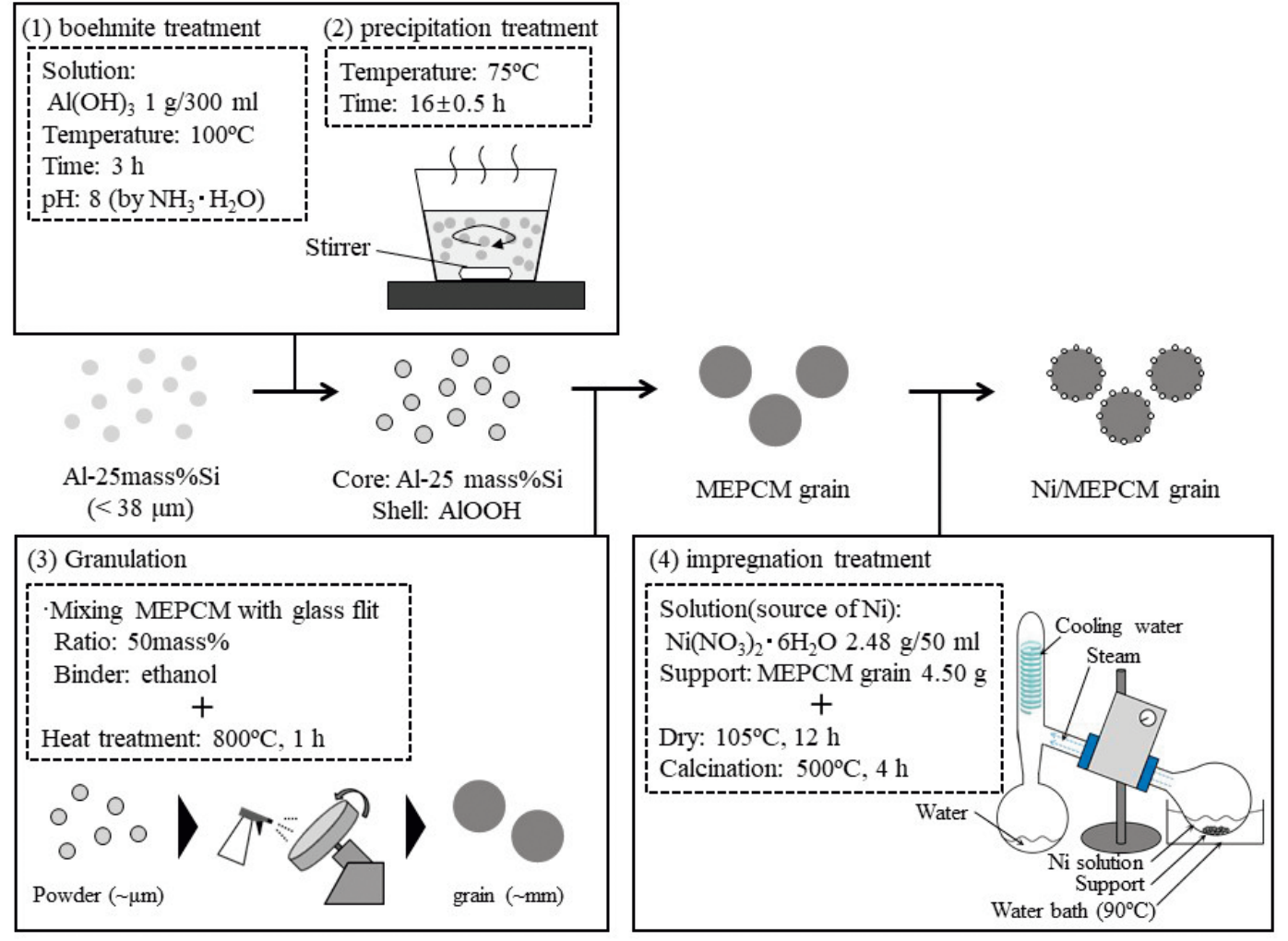

Fig. 1. Preparation of Ni/MEPCM grain from Al-25 mass\%Si by (1) boehmite treatment, (2) precipitation treatment, (3) granulation, (4) impregnation treatment. (Online version in color.) 
て $100 \mathrm{rpm}, 15 \mathrm{~min}$ 混合した。混合粉をパン型転動造粒装置 に投入しエタノールをバインダーに粒状に成型した。成型 した試料を空気雲囲気下, $800^{\circ} \mathrm{C}$ で $1 \mathrm{~h}$ 熱処理し, 潜熱蓄熱 粒子を得た。

触媒は 10 mass $\% \mathrm{Ni} /$ 潜熱蓄熱粒子の調製を狙い, 含浸法 で潜熱蓄熱粒子に担持した。含浸装置としてロータリーエ バポレーターを用いた。まず, フラスコ内で蒸留水 $50 \mathrm{ml}$ 硝酸ニッケル六水和物を $2.48 \mathrm{~g}$ 添加し, 溶解した。次に調 製した処理液に潜熱蓄熱粒子を $4.50 \mathrm{~g}$ 投入し, 溶液を $90^{\circ} \mathrm{C}$ に加熱してフラスコを回転しながら水を蒸発させNiを含 浸した。得られた試料を $105^{\circ} \mathrm{C} て ゙ 12 \mathrm{~h}$ 乾燥し, 空気雲囲気 下, $500^{\circ} \mathrm{C}$ で $4 \mathrm{~h}$ 煆焼した。

\section{$2 \cdot 3$ エタノール水蒸気改質反応による触媒試験}

石英管 $(\phi 20 \mathrm{~mm})$ を反応管として用いて触媒試験を実 施した。Fig.2 は, 触媒試験装置の全体模式図を示す。石英 管に Ni 担持潜熱蓄熱粒子を $3.5 \mathrm{~g}$ 充填した。この際, 触媒 充填層の高さは20 mmであった。触媒試験前に触媒を水 素気流中に $500^{\circ} \mathrm{C} に て 1 \mathrm{~h}$ 保持し, 還元処理した。その後炉 1 , 炉 2 の温度を $550^{\circ} \mathrm{C}$, 炉 3 の温度を $650^{\circ} \mathrm{C}$ まで昇温した。

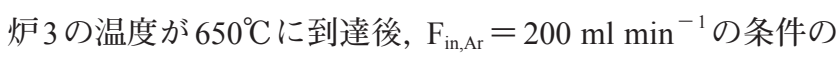
下, エタノールと蒸留水の混合溶液を定量送液ポンプ (東 京理化機械製MP-4000）を用いて投下した。混合溶液の濃 度はエタノール/蒸留水のモル比 $1: 5$ とし, 送液速度は $0.1 \mathrm{ml} \mathrm{min}{ }^{-1}$ とした。液滴は触媒に到達する前に石英管内
の $550^{\circ} \mathrm{C}$ に加熱されている部分で石英ウールに吸収され， 気化した状態で連続的に触媒充填層に流通する。排出ガス が定常となった後, 炉 1 , 炉 2 を $550^{\circ} \mathrm{C} て ゙$ 保持し, 炉 3 のみ熱 供給を停止して $30 \mathrm{~min}$ の間触媒試験をした。また, 比較用 として潜熱蓄熱粒子と同様の手順で調製した $\mathrm{Ni}$ 担持 $\mathrm{Al}_{2} \mathrm{O}_{3}$ 粒 (粒子サイズ : $2 \mathrm{~mm}$ ) も触媒試料に用いた。四重極質量 分析計を用いて排出ガス組成を測定した。

触媒性能を評価するために, 以下の式 (2) で表される水 素収率を指標として用いた $\left(\mathrm{F}_{\text {in }}\right.$ : 入口流量, $\mathrm{F}_{\text {out }}$ : 出口流量 $)$ 。

水素収率 : $\frac{F_{\mathrm{H}_{2}, \text { out }}}{6 F_{\mathrm{C}_{2} \mathrm{H}_{5} \mathrm{OH}, \text { in }}} \times 100$.

\section{$2 \cdot 4$ 試料の特性評価}

反応前後の試料の形状を FE-SEM (日本電子株式会社製 JSM-7001F）にて観察した。試料の相同定をX線回折装置 （Rigaku, Mini Flex）にて実施した。試料の蓄熱密度をDSC (METTLER TOLEDO DSC823e) にて測定した。

\section{3. 結果と考察}

\section{$3 \cdot 1$ 調製後の試料の特性評価}

Fig.3は作製した潜熱蓄熱粒子と $\mathrm{Ni}$ /潜熱蓄熱粒子の外観 を示す。作製した潜熱蓄熱粒子の大きさは1〜3 mmだっ



Fig. 2. Experimental apparatus of catalytic performance analysis for steam reforming of ethanol. (Online version in color.) 
た。含浸処理後，潜熱蓄熱粒子表面の色が灰色から黒色に 変化したが, 粒の形状, 大きさには変化がなく，担持前と同 様の形態を維持していた。この結果より，ガラスフリット を焼結材として成型された潜熱蓄熱粒子は含浸処理に耐え 得る耐久性を持つことがわかった。Fig.4は潜熱蓄熱粒子と 含浸処理後の Ni/潜熱蓄熱粒子表面のSEM画像と EDS によ るマッピング結果を示す。含浸処理前後の試料両方で球状 のMEPCMが観察された。また，含浸処理後のMEPCMの 表面には多数の 100〜200 nm 程度の粒子が出現した。EDS によるマッピング結果より，これらの粒子がNiであること が分かった。以上より，含浸処理により，潜熱蓄熱粒子上 に粒径 100〜200 nmの Ni触媒を担持することに成功した。

Fig.5 はMEPCM 単体と潜熱蓄熱粒子と含浸処理後の Ni/ 潜熱蓄熱粒子と焼結に用いたガラスフリットのXRD回折

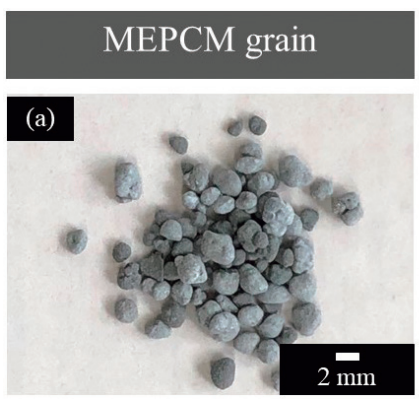

$\mathrm{Ni} / \mathrm{MEPCM}$ grain

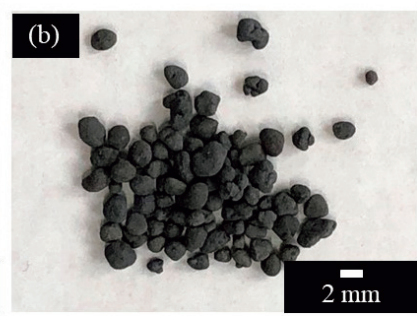

Fig. 3. The appearance of MEPCM grains a) before and b) after impregnation treatment. (Online version in color.)
結果を示す。潜熱蓄熱粒子と含浸処理後の $\mathrm{Ni}$ /潜熱蓄熱粒 子の両方で MEPCM 単体が持つ $\mathrm{Al}, \mathrm{Si}$ のピークが検出され た。このことより成型した粒の中でコアとなる Al-Si合金 は, 粒状化, および含浸処理中にも保護され, 化学的に変 化しなかったことが判明した。含浸処理後の試料からは, $\mathrm{NiO}$ を示すピークが検出された。これは $\mathrm{Ni}$ 源として用いた 硝酸 $\mathrm{Ni}$ 六水和物が, 含浸処理後の熱処理工程で空気䨌囲

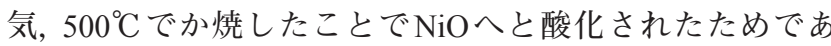
る。また, $\mathrm{Ni}$ 含浸処理前後で $\mathrm{NiO}$ 以外の新たな組成は Ni/ 潜熱蓄熱粒子からは検出されず, $\mathrm{Al}, \mathrm{Si}, \mathrm{NiO}$ を除く全て のピークはガラスフリットが示すピークと一致した。従っ て，これらのピークは全て焼結材を示すものである。

Fig.6は作製した潜熱蓄熱粒子と Ni/潜熱蓄熱粒子の降温 時のDSC 測定結果を示す。両方の試料でPCMの凝固に伴 う放熱ピークが観察された。潜熱量は潜熱蓄熱粒子, $\mathrm{Ni} /$ 潜 熱蓄熱粒子でそれぞれ78.0, $69.9 \mathrm{~J} \mathrm{~g}^{-1}$ だった。 $\mathrm{Ni}$ 担持後 に潜熱量が約 $90 \%$ に減少したことは, 潜熱蓄熱粒子上へ 10 mass\%の Niを担持し, MEPCMの重量比が減少した割合 とほぼ一致した。凝固温度は潜熱蓄熱粒子, $\mathrm{Ni} /$ 潜熱蓄熱粒

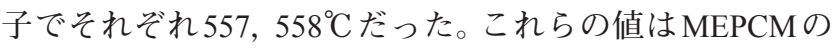
原料である $\mathrm{Al}-25 \mathrm{mass} \% \mathrm{Si}$ 合金の融点である $577^{\circ} \mathrm{C} よ り$ 低 い。これは過冷却現象によるものである。Al-25 mass\% $\%$ Si $\alpha-\mathrm{Al}_{2} \mathrm{O}_{3}$ コア/シェル構造 MEPCM は凝固する際に過冷却現 象が起こることが報告されている ${ }^{16)}$ 。加えて, Al-Si合金系 MEPCM は放熱ピークを2つ持つことも報告されている ${ }^{15)}$

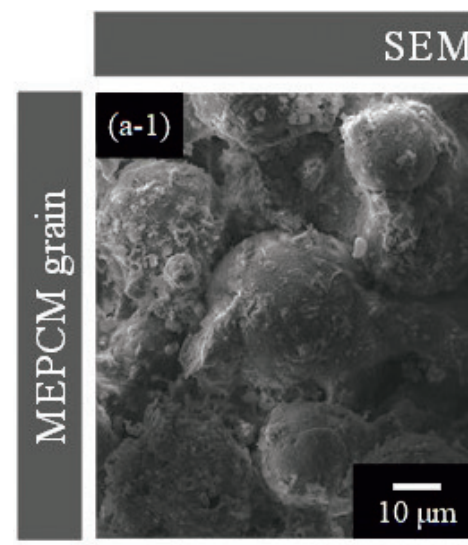

\section{image}
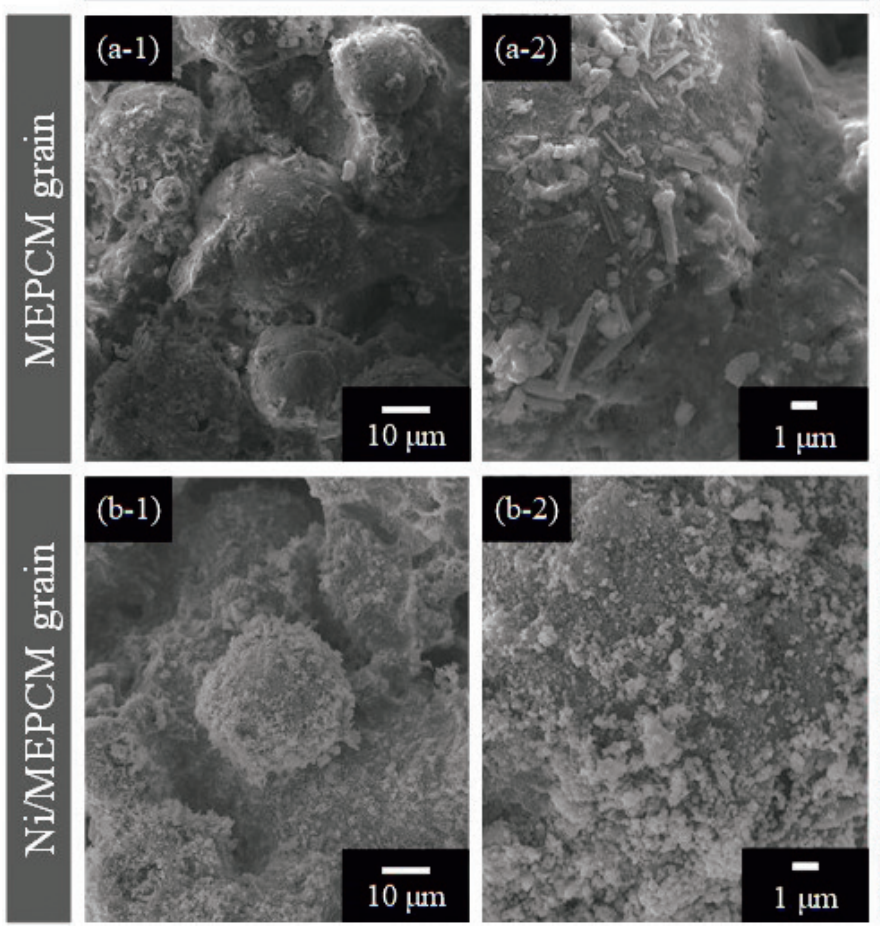
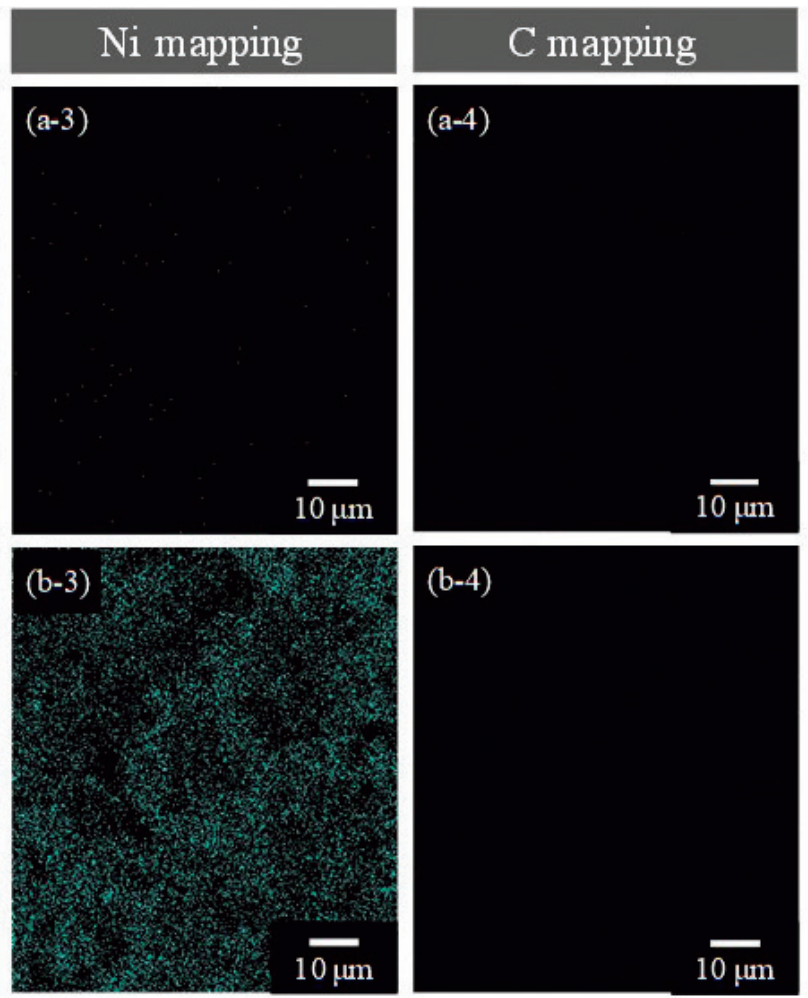

Fig. 4. SEM images and Ni and C mapping by EDS of MEPCM grain a) before and b) after impregnation treatment. (Online version in color.) 
そのため, Fig.6に打いてもそれぞれの蓄熱粒子から放熱 ピークが2つ観測された。

\section{$3 \cdot 2$ エタノールの水蒸気改質反応による触媒試験}

Fig.7は Ni/潜熱蓄熱粒子を用いて触媒試験をした際のa） 出口ガス濃度と, b) 水素収率および充填層温度の変化を 示す。排出ガスからは原料に用いた $\mathrm{C}_{2} \mathrm{H}_{5} \mathrm{OH}$ は検出されず, $\mathrm{H}_{2}, \mathrm{CO}_{2}, \mathrm{CO}, \mathrm{CH}_{4}, \mathrm{H}_{2} \mathrm{O}$ が検出された。試験開始時は $\mathrm{H}_{2}$ 濃 度が約 $62 \%, \mathrm{CO}_{2}$ 濃度が約 $9 \%, \mathrm{CO}$ 濃度が約 $8 \%, \mathrm{CH}_{4}$ 濃度 が約 $3 \%, \mathrm{H}_{2} \mathrm{O}$ 濃度が約 $18 \%$ だった。時間経過とともに $\mathrm{H}_{2}$ 濃度, $\mathrm{CO}$ 濃度は低下し, $\mathrm{CH}_{4}$ 濃度, $\mathrm{H}_{2} \mathrm{O}$ 濃度は増加した。 $30 \mathrm{~min}$ 後は $\mathrm{H}_{2}$ 濃度が約 $38 \%, \mathrm{CO}_{2}$ 濃度が約 $10 \%, \mathrm{CO}$ 濃度が 約 $0 \%, \mathrm{CH}_{4}$ 濃度が約 $12 \%, \mathrm{H}_{2} \mathrm{O}$ 濃度が約 $40 \%$ だった。エタ ノールの水蒸気改質はエタノールが炭素原子を二個含むこ とにより，メタンやメタノールの水蒸気改質と比較して多 くの副反応が存在することが知られている ${ }^{21)}$ 。以下にエタ ノールの水蒸気改質において主要な副反応の一部を示す。

$$
\begin{aligned}
& \text { 2) } \mathrm{C}_{2} \mathrm{H}_{5} \mathrm{OH}+\mathrm{H}_{2} \mathrm{O} \rightarrow 4 \mathrm{H}_{2}+2 \mathrm{CO} \quad \Delta \mathrm{H}_{298 \mathrm{~K}}=256 \mathrm{~kJ} \mathrm{~mol}^{-1} \ldots \\
& \text { 3) } \mathrm{C}_{2} \mathrm{H}_{5} \mathrm{OH}+2 \mathrm{H}_{2} \rightarrow 2 \mathrm{CH}_{4}+\mathrm{H}_{2} \mathrm{O} \quad \Delta \mathrm{H}_{298 \mathrm{~K}}=-157 \mathrm{~kJ} \mathrm{~mol}^{-1} \ldots
\end{aligned}
$$

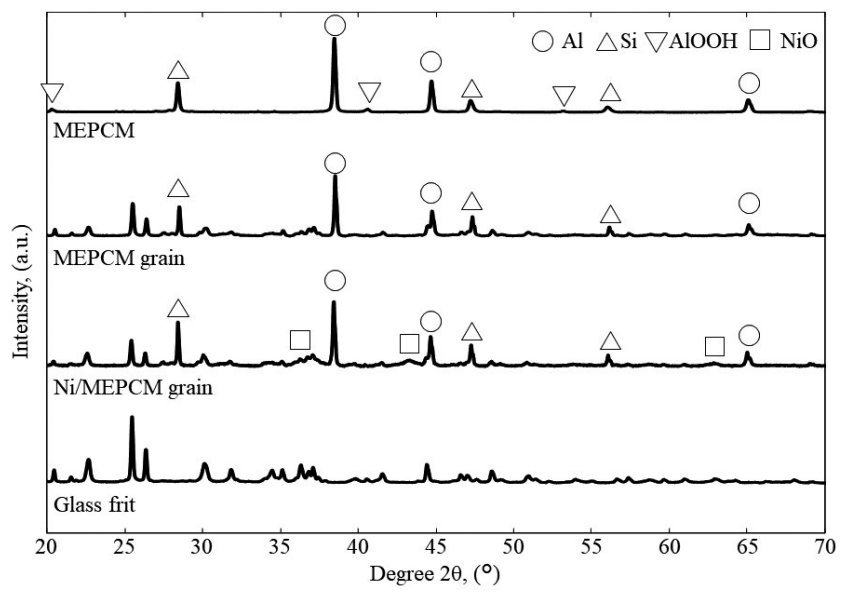

Fig. 5. XRD patterns of MEPCM, MEPCM grain and MEPCM after impregnation treatment.



Fig. 6. DSC curves of MEPCM grain before and after impregnation treatment during heat release $\left(\mathrm{T}_{\mathrm{m}}\right.$ : Melting point, $\Delta \mathrm{H}$ : Latent heat).

$$
\begin{aligned}
& \text { 4) } \mathrm{C}_{2} \mathrm{H}_{5} \mathrm{OH} \rightarrow \mathrm{CO}+\mathrm{CH}_{4}+\mathrm{H}_{2} \quad \Delta \mathrm{H}_{298 \mathrm{~K}}=49 \mathrm{~kJ} \mathrm{~mol}^{-1} \ldots \ldots \ldots \text { (5) } \\
& \text { 5) } \mathrm{CO}+\mathrm{H}_{2} \mathrm{O} \rightarrow \mathrm{CO}_{2}+\mathrm{H}_{2} \quad \Delta \mathrm{H}_{298 \mathrm{~K}}=-41 \mathrm{~kJ} \mathrm{~mol}^{-1} \ldots \ldots \ldots \ldots \ldots . . .
\end{aligned}
$$

排出ガスから $\mathrm{CO} \mathrm{CH}_{4}$ が検出されたことから，目的と する反応の他，上記の副反応も進行したと考えられる。

触媒試験の際，触媒充填層は放熱状態にあるため時間 経過とともに温度は降下した。Fig.7b）が示す通り温度の 降下とともに水素収率も低下した。触媒充填層の温度が $650^{\circ} \mathrm{C}$ の時は水素収率は約 $52 \%$ だったが, 触媒充填層の温 度が $450^{\circ} \mathrm{C}$ の時の水素収率は約 $26 \%$ であった。触媒試験中, 温度はなだらかに降下したが約 $550^{\circ} \mathrm{C}$ 付近にて温度変化の 緩和が見られた。これはPCMが凝固したことにより凝固 潜熱を放出したためである。また, 触媒試験中は水素収率 も温度と同様に降下したが，温度変化が緩和した約 $550^{\circ} \mathrm{C}$ 付近にて収率変化の緩和が見られた。これはPCMからの 放熱が触媒充填層の温度を維持したことで, 水素収率も維 持されたことを示唆している。

Fig.8は Ni/ $/ \mathrm{Al}_{2} \mathrm{O}_{3}$ 粒子を用いて触媒試験をした際のa）出 口ガス濃度とb）水素収率および充填層温度の変化を示す。

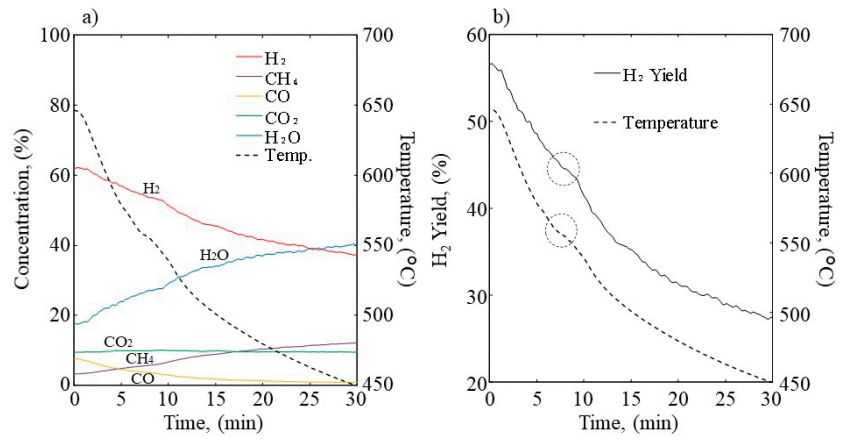

Fig. 7. a) Concentration of outlet gas and b) $\mathrm{H}_{2}$ yield and temperature of catalytic packed bed with time over $\mathrm{Ni} /$ MEPCM grain during heat release (Inlet material: 17 mol\% ethanol solution $0.1 \mathrm{ml} \mathrm{min}^{-1}$ and career gas: $\mathrm{Ar}$ $200 \mathrm{ml} \mathrm{min}^{-1}$ ). (Online version in color.)
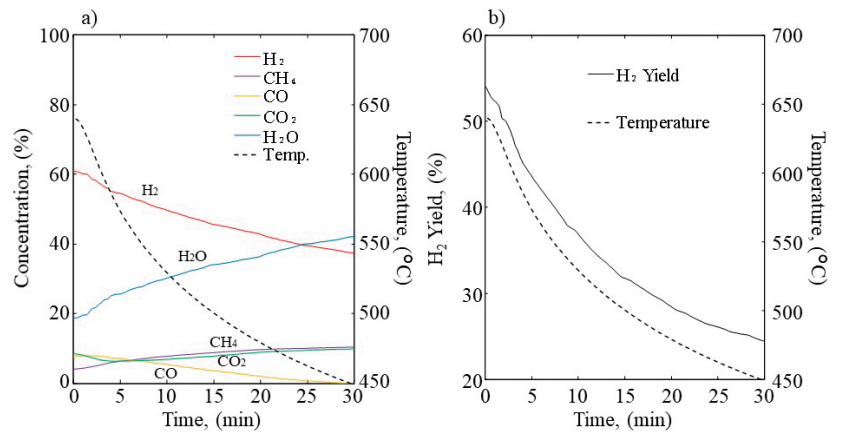

Fig. 8. a) Concentration of outlet gas b) $\mathrm{H}_{2}$ yield and temperature of catalytic packed bed with time over $\mathrm{Ni} /$ $\mathrm{Al}_{2} \mathrm{O}_{3}$ grain during heat release. (Inlet material: $17 \mathrm{~mol} \%$ ethanol solution $0.1 \mathrm{ml} \mathrm{min}^{-1}$ and career gas: Ar $200 \mathrm{ml}$ $\mathrm{min}^{-1}$ ). (Online version in color.) 
出口ガス濃度は $\mathrm{Ni} /$ 潜熱蓄熱粒子を用いた場合と同様の傾 向が得られた。水素濃度は $\mathrm{Ni} /$ 潜熱蓄熱粒子を用いた場合 と比較してわずかに低かった。

$\mathrm{Ni} / \mathrm{Al}_{2} \mathrm{O}_{3}$ 粒子を用いて触媒試験をした際の水素収率と充 填層温度の変化はFig.8 b) が示す通り温度, 水素収率とも に降下し続けた。また， $\mathrm{Ni} /$ 潜熱蓄熱粒子を用いた場合に見 られた変化の緩和は温度・水素収率のどちらにも見られな かった。従って， Ni/潜熱蓄熱粒子を用いた場合に見られた 温度, 水素収率の変化の緩和は, PCMの放熱機能によるも

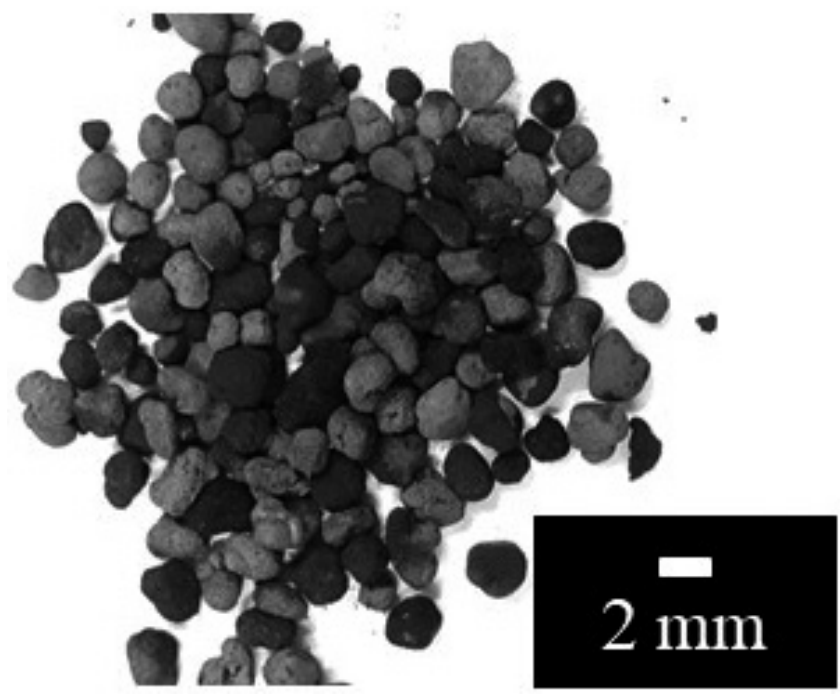

Fig. 9. The appearance of Ni/MEPCM grain after catalytic test.
のと考えられる。以上より，潜熱蓄熱材料であるPCMによ り触媒反応熱を制御できる可能性が見出された。

\section{$3 \cdot 3$ 触媒試験後の試料の特性評価}

Fig.9 は触媒試験後の Ni/潜熱蓄熱粒子の外観を示す。触 媒試験前と比較して粒子の形状や大きさに変化はなく, 粒 径は 1〜3 mmだった。粒子表面の色は黒色物と灰色物の二 種類の粒子が得られた。Fig.10は触媒試験後の Ni/潜熱蓄熱 粒子のSEM画像とEDSによるマッピング結果を示す。黒 色に変色した $\mathrm{Ni} /$ 潜熱蓄熱粒子の表面が繊維状の析出物で 覆われた。EDS マッピングの結果，この析出物が炭素であ ることが分かった。一方で灰色の粒子の表面に炭素の析出 は見られなかった。長時間の触媒試験により全ての Ni/潜 熱蓄熱粒子が炭素に覆われ，触媒が失活する可能性があ る。

Fig.11は触媒試験後の Ni/潜熱蓄熱粒子の XRD 回折結果 を示す。a）は水素還元のみをした Ni/潜熱蓄熱粒子，b）は 水素還元後, 触媒試験をした $\mathrm{Ni} /$ 潜熱蓄熱粒子の XRD回折 結果である。どちらの試料にも, 触媒試験前の $\mathrm{Ni} /$ 潜熱蓄熱 粒子で検出された $\mathrm{PCM}$ 示す $\mathrm{Al}, \mathrm{Si}$ ピークと焼結材と一 致するピークが出現した。従って, 触媒試験中もコアであ る $\mathrm{Al}-\mathrm{Si}$ 合金は保護され，化学的に変化しなかった。触媒試

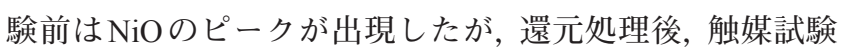
後は $\mathrm{NiO}$ のピークは出現せず, $\mathrm{Ni}$ のピークが出現した。こ れは触媒試験前に水素により $\mathrm{NiO}$ が $\mathrm{Ni}$ に還元したためで ある。
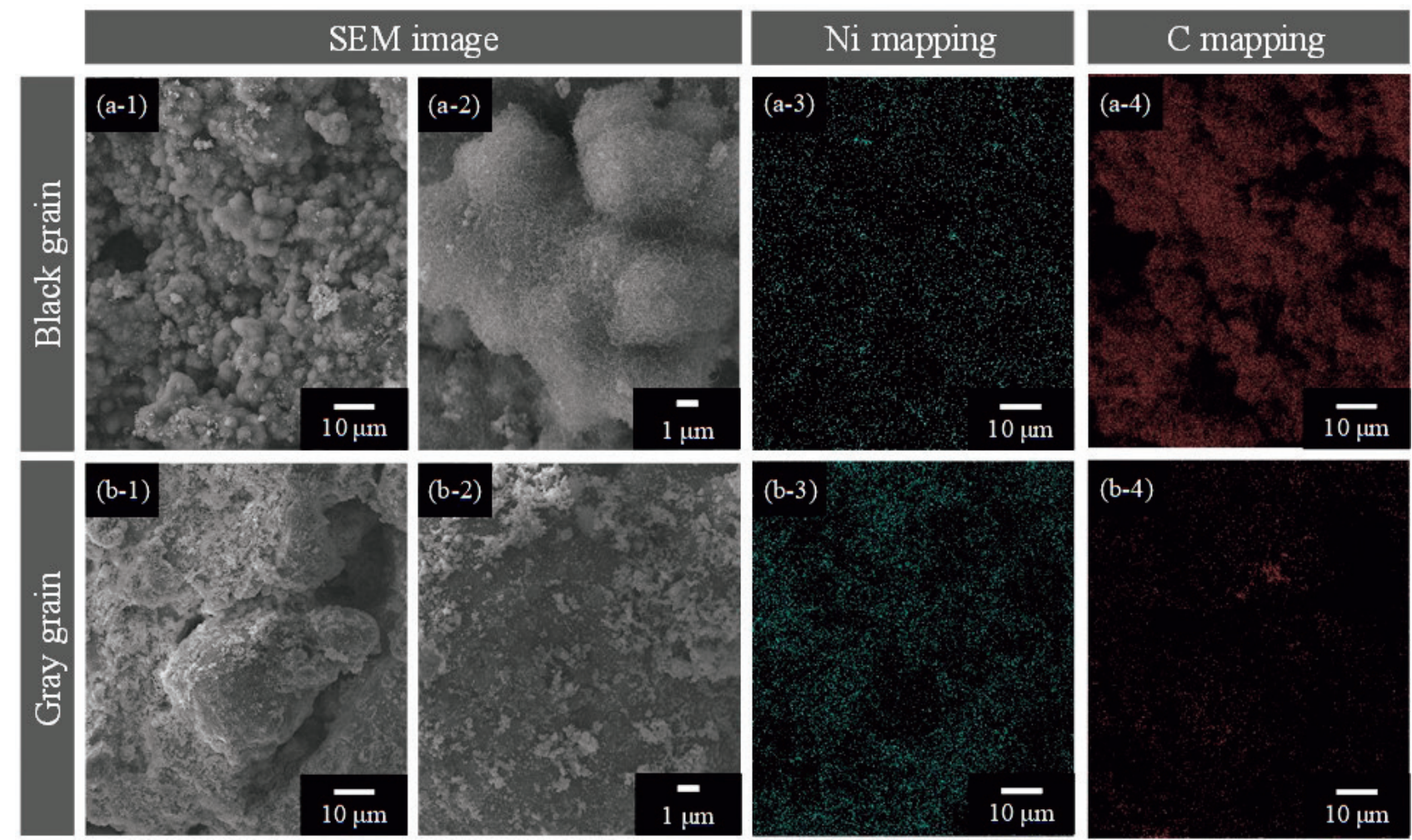

Fig. 10. SEM images and Ni and C mapping by EDS of Ni/MEPCM grain after catalytic test, a) black grain and b) gray grain. (Online version in color.) 


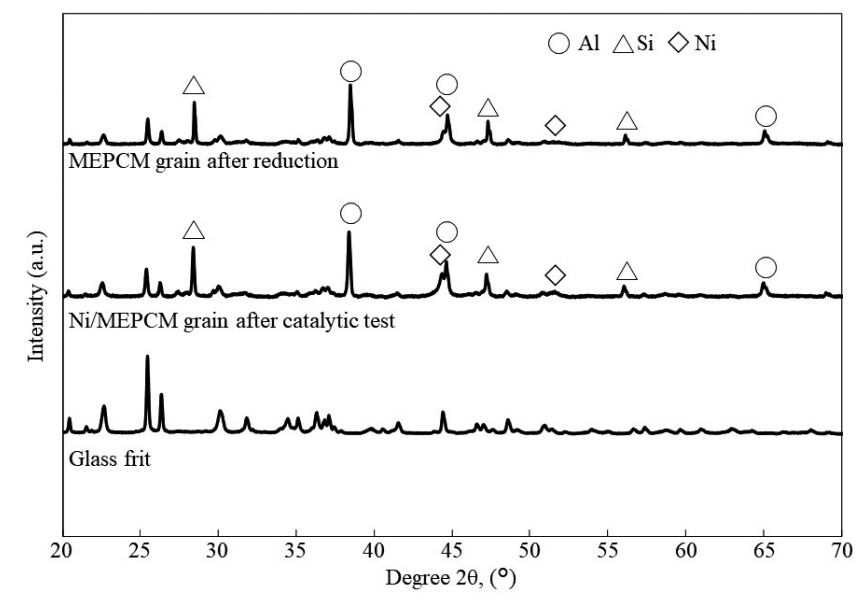

Fig. 11. XRD patterns of Ni/MEPCM grain after reduction and $\mathrm{Ni} / \mathrm{MEPCM}$ grain after catalytic test and glass frit.

Fig.12 は触媒試験後の Ni/潜熱蓄熱粒子の放熱時の DSC カーブを示す。触媒試験前と同様にPCMの凝固に伴う吸

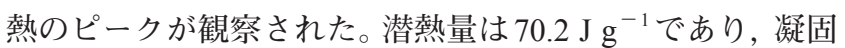

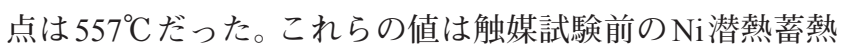
粒子が示した值と一致する。即ち, 触媒試験に $\mathrm{Ni} /$ 潜熱蓄熱 粒子を使用しても蓄熱材料としての性能は劣化しないこと が分かった。

\section{4. 結論}

MEPCM と焼結材であるガラスフリットを質量比 $1 ： 1$ で 混合し, 転動造粒法で成型することで潜熱蓄熱粒子 (粒子 サイズ：2 mm）を作製した。作製した潜熱蓄熱粒子に含浸 処理にて $\mathrm{Ni}$ を担持し, $\mathrm{Ni} /$ 潜熱蓄熱粒子を調製した。温度 を下げながら $\mathrm{Ni} /$ 潜熱蓄熱粒子を触媒としてエタノールの 水蒸気改質を実施した結果, 触媒充填層の温度が $650^{\circ} \mathrm{C}$ の 時は $52 \%$ の水素収率を得たが, 温度が $450^{\circ} \mathrm{C}$ まで低下した 際の水素収率は $26 \%$ まで低下した。触媒試験中, 約 $550{ }^{\circ} \mathrm{C}$ にて PCMの凝固熱による温度変化の緩和が見られた。こ れに伴い, 水素収率の変化にも緩和が見られた。この現 象は, $\mathrm{Ni} / \mathrm{Al}_{2} \mathrm{O}_{3}$ 粒子を触媒とした場合の結果には見られな かった。

以上より, 潜熱蓄熱材料である PCM は吸熱反応系へ熱 供給可能であることが分かった。

\section{謝辞}

本研究の一部は, 一般社団法人日本鉄鋼協会 環境・エ ネルギー・社会工学部会 未利用熱エネルギー有効活用研 究会のご支援によるものです。ここに謝意を表します。

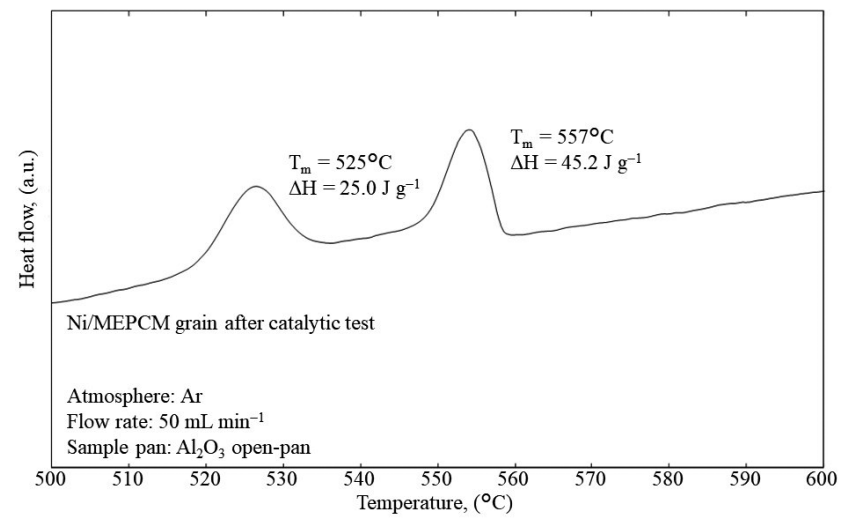

Fig. 12. A DSC curve of Ni/MEPCM grain after catalytic test during heat release. ( $\mathrm{T}_{\mathrm{m}}$ : Melting point, $\Delta \mathrm{H}$ : Latent heat)

\section{文献}

1 ) T.Akiyama, R.Takahashi and J.Yagi: ISIJ Int., 29(1989), 447.

2 ) T.Akiyama, H.Sato, A.Muramatsu and J.Yagi: ISIJ Int., 33(1993), 1136.

3 ) A.Muramatsu, H.Sato, T.Akiyama and J.Yagi: ISIJ Int., 33(1993), 1144.

4 ) E.Kasai, T.Kitajima, T.Akiyama, J.Yagi and F.Saito: ISIJ Int., 37(1997), 1031.

5 ) T.Akiyama, K.Oikawa, T.Shimada, E.Kasai and J.Yagi: ISIJ Int., 40(2000), 286

6 ) T.Mizuochi, T.Akiyama, T.Shimada, E.Kasai and J.Yagi: ISIJ Int., 41(2001), 1423.

7 ) T.Shimada, V.Kochura, T.Akiyama, E.Kasai and J.Yagi: ISIJ Int., 41(2001), 111 .

8 ) N.Maruoka and T.Akiyama: J. Chem. Eng. Jpn., 36(2003), 794.

9 ) G.Nardin, A.Meneghetti, F.Dal Magro and N.Benedetti: Appl. Energy, 136(2014), 947.

10) F.Dal Magro, A.Meneghetti, G.Nardin and S.Savino: Energy Convers. Manag., 104(2015), 78.

11) F.Dal Magro, M.Jimenez-Arreola and A.Romagnoli: Appl. Energy, 208(2017), 972.

12) N.Maruoka and T.Akiyama: ISIJ Int., $\mathbf{4 2 ( 2 0 0 2 ) , 1 1 8 9 .}$

13) N.Maruoka, K.Sato, J.Yagi and T.Akiyama: ISIJ Int., 42(2002), 215.

14) N.Maruoka, T.Mizuochi, H.Purwanto and T.Akiyama: ISIJ Int., 44(2004), 257.

15) T.Nomura, N.Sheng, C.Zhu, G.Saito, D.Hanzaki, T.Hiraki and T.Akiyama: Appl. Energy, 188(2017), 9.

16) T.Nomura, J.Yoolerd, N.Sheng, H.Sakai, Y.Hasegawa, M.Haga, G.Saito and T.Akiyama: Sol. Energy Mater. Sol. Cells, 187(2018), 255.

17) N.Sheng, C.Zhu, G.Saito, T.Hiraki, M.Haka, Y.Hasegawa, H.Sakai, T.Akiyama and T.Nomura: J. Mater. Chem. A, 6(2018), 18143.

18) T.Nomura, J.Yoolerd, N.Sheng, H.Sakai, Y.Hasegawa, M.Haga and T.Akiyama: Sol. Energy Mater. Sol. Cells, 193(2019), 281.

19) N.Sheng, C.Zhu, H.Sakai, T.Akiyama and T.Nomura: Sol. Energy Mater. Sol. Cells, 191(2019), 141.

20) Z.Wang, C.Wang, S.Chen and Y.Liu: Int. J. Hydrog. Energy., 39(2014), 5644.

21) P.D.Vaidya and A.E.Rodrigues: Chem. Eng. J., 117(2006), 39. 